\title{
FINTECH, THE NEW ERA OF FINANCIAL SERVICES
}

The research aims to fill the gap in the current academic literature regarding the appearance of innovation-focused financial technology (fintech) companies. The analysis provides a conceptual overview of the key value drivers behind fintechs, including the utilization of resource-based theories, business models, human-centered design and open innovation. The article introduces how fintechs can serve as an enabler of innovation in the incumbent financial sector and can have positive effects on the triple-bottom-line by solving the problems of people who live at the bottom-of-the-pyramid.

Keywords: financial technology, fintech, business models, key-value-drivers, evolution of fintech, triple-bottom-line, bottom-of-the-pyramid

$\mathrm{T}$ he term 'fintech' has appeared recently in business journals to describe the disruptive challenge to the financial sector of the introduction of faster, cheaper and human-centered financial services. The term has become a buzzword among private and institutional investors who invested more than 50 billion dollars into the sector between 2010 and 2015 (Accenture, 2015). The visionary statement made by Bill Gates in 1994 that "banking is necessary, banks are not" has become a self-reinforcing prophecy, with 6,000 - 7,000 fintech companies across the world now trying to obtain a slice of the banking industry's profitable business. Strategic advisory firms have already put the emerging fintech trend at the top of their agendas, with the goal of providing universal banks with a better understanding of likely future scenarios. The growing interest in fintech will soon be visible in the academic literature, but there is currently a large knowledge deficit about this field. Fintech is an evolving concept which has so far created little historical evidence or statistically significant time-series data for analysis, leaving researchers only secondary data with which to work, or sponsored research carried out by large advisory companies. As signs are already emerging that such financial technologies have the ability to significantly impact the use of cash and current banking and financial practices, and may empower individuals living at the bottom of the pyramid, the validity of research into the various areas of fintech and the financial sector is apparent.

The goal of the research described in this paper was to fill a gap in the yet evolving and under-researched fintech literature by providing an alternative approach to understanding how the different ecosystems and layers of business have catalyzed the appearance of innovation-focused fintech companies, and what the key value drivers of their success have been. Key value drivers are identified by finding common trends in current research and also by building on the author's professional experience in the field. The paper supplies researchers, economists and financial professionals with a better understanding of which areas of the sector require further in-depth research, and offers a holistic understanding of the subject. It is not the goal of this paper to provide an in-depth analysis of the specific domains fintech companies are operating in such as lending or payment transfers -, or to generate an exclusive way of understanding the role that fintech can play in the financial sector, but rather to invoke new ideas by offering an alternative, multi-layered evolutionary approach that may be used as a guideline in further academic research into the subject. Meanwhile, the article focuses on global trends and links the concept of financial technologies with social, environmental and economic aspects (the triple-bottom-line); it also paves the way for examination of their effect on the Hungarian financial sector. Although the research uses the term 'banks' frequently, its findings generally represent the financial industry as whole, including insurance companies, pensions funds, mutual funds and various other financial intermediaries.

\section{Defining fintech}

The fintech sector is evolving fast, but a great variety of definitions of the concept exist in academic practice and business journals. Meanwhile, even if stakeholders agree about the core elements of the term, its scope has not been clearly defined. Opinions vary about whether only newly emerging technology-based financial companies can be referred to as fintech, or if incumbents may also be regarded as fintech, if they are innovating a new technology-based service or product. Nor it is clear if there is a market capitalization threshold, which may be used to distinguish fintech from traditional financial intermediaries. Despite the differences, definitions agree that fintech refers to companies that develop financial services and products by relying on much more intense use of information technology.

You can see in the Table 1. that all definitions of the fintech sector have their merits and serve the purposes of the authors' research or business objectives. Arner, Barberis and Buckley were some of the first scholars to examine the evolution of fintech using a broad definition of the term that proposed that all incumbent and new financial companies and industry participants could be regarded as fintech, regardless of their size, business model or product portfolio. The approach is useful in research that employs an evolu- 
tionary perspective, as the development of financial technologies are classified into three major, sequential phases.

Table 1.

\section{Definitions of fintech}

\begin{tabular}{|c|c|c|}
\hline Definitions & Source & Year \\
\hline $\begin{array}{l}\text { "Financial technology" or "FinTech" } \\
\text { refers to technology-enabled financial } \\
\text { solutions. The term FinTech is not } \\
\text { confined to specific sectors (e.g. } \\
\text { financing) or business models (e.g. } \\
\text { peer-to-peer (P2P) lending), but instead } \\
\text { covers the entire scope of services and } \\
\text { products traditionally provided by the } \\
\text { financial services industry. }\end{array}$ & $\begin{array}{l}\text { Arner, DW; } \\
\text { Barberis, JN; } \\
\text { Buckley, RP }\end{array}$ & 2015 \\
\hline $\begin{array}{l}\text { Financial innovation can be } \\
\text { defined as the act of creating and } \\
\text { then popularizing new financial } \\
\text { instruments as well as new financial } \\
\text { technologies, institutions and markets. } \\
\text { It includes institutional, product and } \\
\text { process innovation. }\end{array}$ & Farha Hussain & 2015 \\
\hline $\begin{array}{l}\text { Fintech is a service sector, which uses } \\
\text { mobile-centered IT technology to } \\
\text { enhance the efficiency of the financial } \\
\text { system. }\end{array}$ & $\begin{array}{l}\text { Kim, Y., Park, } \\
\text { Y. J., \& Choi, } \\
\text { J. }\end{array}$ & 2016 \\
\hline $\begin{array}{l}\text { An economic industry composed of } \\
\text { companies that use technology to } \\
\text { make financial systems more efficient. }\end{array}$ & McAuley, D. & 2015 \\
\hline $\begin{array}{l}\text { Fintech is a portmanteau of financial } \\
\text { technology that describes an emerging } \\
\text { financial services sector in the } 21 \text { st } \\
\text { century. }\end{array}$ & Investopedia & 2016 \\
\hline $\begin{array}{l}\text { FinTech describes a business that aims } \\
\text { at providing financial services by } \\
\text { making use of software and modern } \\
\text { technology. }\end{array}$ & $\begin{array}{l}\text { Fintech } \\
\text { weekly }\end{array}$ & 2016 \\
\hline $\begin{array}{l}\text { Organizations combining innovative } \\
\text { business models } \\
\text { and technology to enable, enhance and } \\
\text { disrupt financial services }\end{array}$ & Ernst\&Young & 2016 \\
\hline
\end{tabular}

Hussain, Kim et al. and McAuley state that fintech refers to companies that not only use IT as a differentiator, but which also strive to provide more efficient services, streamlined processes and to enter traditionally non-banking markets. Investopedia and Fintech weekly, two specialized media outlets, use a similarly broad definition to that of Arner et al. but focus more on the new technology premises of fintech, viewing the related companies as new market players for the twenty-first century

Ernst \& Young is a global advisory company with a broad clientele of large companies, including banks and insurance companies. Their definition of fintech implies that all organizations, not just startup companies but also traditional banks, telecommunication companies, utilities and so on, can become part of the fintech phenomenon if they can craft innovative business models and the related supporting technology. This is a value-added approach as it relates to the business models used in fintech.
Meanwhile, all the definitions capture an important feature of fintech; namely, that there is no consensus about where the boundaries of the newly emerging sector lie. Arriving at a common definition is very important as fintech companies are already providing financial services to millions of people and are transferring, exchanging or lending billions of dollars. As the economic and social impact of fintech grows, it is increasingly difficult for legislators to clearly communicate their expectations towards them, leading to confusion and potentially opening up hazardous loopholes in the financial system. Legislators are imposing transparent and rather strict compliance rules on banks in the various areas of risk, liquidity and balance-sheet management, as well as legal compliance, and require them to set aside large pools of money to hedge credit default events. To comply with IT regulatory expectations, banks have to continuously improve their IT security systems using funds, which may be equal to the total equity of smaller fintech startups. This state of unevenness between incumbents and (less or) non-regulated fintech is creating not just a competitive disadvantage for banks, but generating unforeseeable threats for customers in the form of cyber-attacks, bankruptcies or data-leakages. Legislators are currently struggling to fit fintech into existing legal frameworks, as these were designed for a different environment consisting of large, traditional financial institutions. Too much regulation can burden innovation efforts, while under-regulation can impose an unfair advantage on new entrants due to their lower legal costs and overheads, and create higher social costs due to fraudulent activity and non-existent customer protection (Douglas, 2016).

In an attempt to address the shortcomings of current definitions, this paper uses the author's own definition to distinguish fintech from traditional, transforming or already digitized financial institutions and to emphasize the importance of technology, service and business model design and the regulatory environment with regard to fintech companies. The aim is to solidify understanding for further studies and research, but also provide a wide enough definition that captures all the current economic activities of the sector.

\section{Fintech refers to non- or not fully regulated ventures whose goal is to develop novel, technology-enabled financial services with a value-added design that will transform current financial practices.}

Fintech companies are being established to improve the financial services currently being offered by traditional financial institutions. To be able to examine the differences between incumbent financial institutions and fintech companies, we further clarify the term fintech in this research with the aim of making a clearly delineated and distinguishable, researchable and comparable separation between market participants. The paper additionally distinguishes between financial institutions based on their level of innovation in terms of developing more user-centered services. Among incumbent financial institutions, 
traditional banks have typically not felt the pressure to examine and adjust their business models, and have a very limited digital footprint. These banks may still believe in traditional bricks-and-mortar banking, maintain sophisticated but costly branch infrastructure, and build their sales organizations around in-branch sales channels. Additionally, such banks may have accumulated significant technology-related debt by running on legacy banking IT systems that are expensive to support, weakly adaptive to new customer needs, and whose legacy commits the bank to pursuing non-digital initiatives. These are the very banks that will be most affected by the rapid growth in digitized and more efficient financial players.

Banks, which have already started experimenting with re-designing their business models to some extent, but have not yet fully digitized their processes and modernized their backend systems will be referred to in this paper as transformational banks. These are the majority of banks, as there are no large global financial institutions today, which have not yet heard of the challenge posed to them by newly emerging fintech companies. These institutions have the ability to steer their business strategies in a more sustainable and competitive direction, and by leveraging their advanced infrastructure, large client bases, abundant funding opportunities and preexisting regulatory compliance, such transformational banks can play a significant role in the evolution of the financial sector.

The most advanced, already highly successful transformational banks, which have arrived at the end of the process of transformation and made it business as usual to innovate in the digital space may be called digital banks, or neo-banks (King, 2014). Digital banks are not greatly different to fintech companies as they typically use advanced, highly digitized core banking systems that can rapidly implement new services. Digital banks are familiar with digital channel management and have a significant digital footprint with sophisticated non-branch strategies. Moreover, digital banks are compliant with regulations, and many of them have solid and profitable business models. Digital or neo-banks are emerging rapidly as many fintech companies have decided to move in this direction and have applied for banking licenses. These digital banks may be able to capture many of the positive benefits of fintech, while also working transparently and under the eyes of regulators.

The distinction between traditional players and new, disruptive entrants is necessary as evidence shows that fintech companies are already having an impact on the digitization of the banking sector. Although not within the scope of this research, it is also evident that each different type of bank is faced with different choices, opportunities and threats when it comes to deciding how to deal with fintech companies.

\section{Outlook on the emerging global fintech scene}

Although data about the total number of fintech companies varies based on the research method, there are agreed to be approximately 6,000 - 7,000 fintech companies around the world (Forbes, 2015). As investment flows into the sector in large volumes, new entrants emerge on a daily basis. Almost a billion dollars' worth of investment went into the sector in December 2015 alone, and this had increased to 7 billion USD by January, 2016 (Let's talk payments, 2016). Fintechs are venturing into all domains that previously were the privilege of universal banks or global financial institutions. The research company $\mathrm{CB}$ Insights categorized two hundred fifty of the largest fintech companies that are transforming the current financial sector. This research shows that fintech is already present in almost all major business domains previously served by traditional financial institutions: business lending, capital markets and trading, credit score and analytics, financial services and infrastructure, general lending, insurance, merchant services, mortgage lending, personal and customer lending, processing and payments infrastructure, regulatory and compliance, real estate investing, and wallets and money transfer (CB Insights, 2017).

Fintech is a global phenomenon with strong international players from Silicon Valley to London, Hong Kong, Beijing, Sydney, and Singapore. 'Finovate' started out as one of the largest fintech conferences and event organizers but is these days also an important source of up-todate fintech news and company valuations. Finovate has attempted to aggregate all the major fintech companies in the world and categorize them by domain and company valuation. Categories include unicorns (companies valued at or more than one billion dollars), and semi-unicorns (fintech companies which are valued at more than 500 million dollars). Thirty-six fintech unicorns and 34 semi-unicorns had been identified as of May, 2015. Only two months later, the number of unicorns had risen from 36 to 48, and semi-unicorns from 34 to 37 . This rapid growth indicates the strong dynamics of the fintech sector. However, it is not yet known whether this growth is sustainable, and nor has the accuracy of the valuations of current fintech companies been assessed.

\section{Unicorns and semi-unicorns by domains}

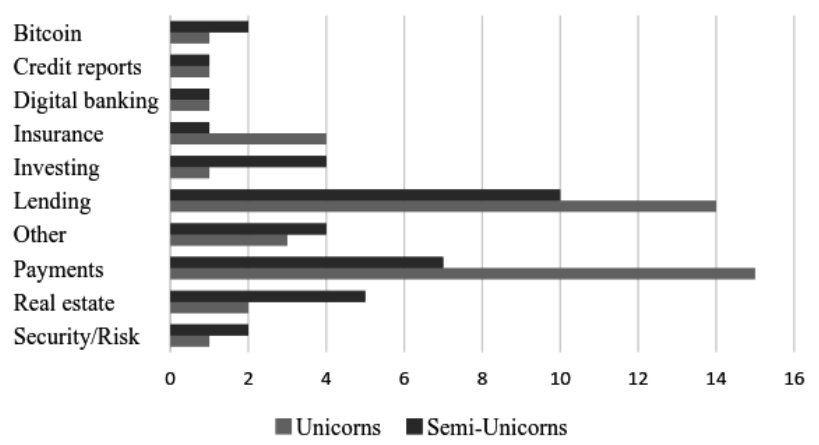

Source: Author's own cunstruction based on Finovate's list of July, 2015

Table 2. shows that fintech companies are mainly focusing on innovating in the fields of lending and payment, but their interest in the insurance, investment, real estate, 
bitcoin and security industries is also growing quickly. Payments and lending became the first areas for disruption because bank customers had the strongest negative perceptions about these banking activities (payments - especially international remittance transfers - have traditionally been expensive and slow, taking up to 2-3 business days). The valuation of fintech unicorns is attracting interest from investors who are willing to invest into these companies. As financial investors generally seek above-average returns on their investments to balance the higher risk of their investment, we can assume that they are looking to grab a slice of the potentially extensive profits generated by these companies. Profit can be made either by reducing costs, or increasing revenues and margins compared to traditional financial intermediaries. The specific details of company calculations are not disclosed due their secretive nature, although we can assume that fintech companies are generally looking to process optimization, the extensive use of information technology and reduced overheads to increase their competitiveness and to offer products and services to market segments which were previously either unreached by traditional banks (e.g.: M-PESA) or were associated with high margins (e.g.: remittance transfers). The bottom-line effect on society has still to be researched to better understand the total cost imposed by traditional banks on society, and how fintech is increasing or reducing this.

Lending is another major target for fintech companies, as the aversion to extending credit of banks caused by the financial crisis made it much harder for customers to obtain personal or business loans. The lending practices of traditional financial institutions have been widely researched with regard to the cost and efficiency of information-gathering on clients, decreasing information asymmetry, and taking into consideration other soft client data that is gathered during relationship banking practices. Extensive brick-and mortar branch networks provided a way to decrease borrower-lender distance, reduce moral-hazard (Chan - Thakor, 1987), and served as a barrier to entry to financial institutions with low capital resources. Reducing distance is an important part of lending, as it helps to improve information gathering for both lenders and borrowers. As research shows, banks were willing to lend to customers and small-businesses about whom they had better information, mostly gathered via their close relationships to the client. Large banks which were able to acquire other banks could increase their concentration in an area (Bikker - Haaf, 2002; DeYoung et al., 2006), further centralizing their power to use information about lenders. Credit to small businesses is a key driver for the economy, and borrowers who had been closer to banks were in an advantageous position to lender farther away from their financial institutions (Aagrwal - Hauswald, 2010). Neo-banks and fintechs saw the market opportunity in building a community of lenders and borrowers and innovated the crowdfunding business model. Crowdsourced lending benefits individuals with a lack of funds by giving them access to capital at reasonable rates of interest, and creating a revenue stream for lenders who can obtain above-average yields on their funds. This competitive edge, and being able to tackle lending in a modular fashion - only operating in a small domain - opened up a great advantage in terms of competing with large financial institutions (Haas et al., 2015). Modularity enabled the first peer-to-peer (P2P) online lending marketplaces to start their operations. The disadvantage of not personally knowing customers was overcome by superior data analysis and by using internet-based platforms to decrease the distance between lenders and borrowers (Bachmann et al., 2011). These early successes of fintechs lead back to a question of design, not just at the intra-company level but also for the banking system as a whole (Bhattacharya - Thakor, 1993). The question arises whether there is a need for universal banks or if a modular approach would be a better for providing an optimized customer service. An examination of the concentration of banks and the relationship between the success of fintechs in a given area is yet to be done (Beck - Demirgüç-Kunt - Levine, 2000). Meanwhile, lending platforms have improved the lender-borrower relationship by decreasing distance between counterparties but have also introduced risks previously dealt with by banks. P2P lending platforms have opened the opportunity to non-professional investors and households to provide funding for borrowers through leading platforms. While P2P could generate extra income for families, a higher overall level of risk has been created, on top of moral hazard, as households may lose money on the loans they supplied in the case of borrower default or non-payment. The subject of P2P lending is a valid subject of future research, with a sole focus on this subject.

\section{The evolution of fintech - two approaches}

Fintech is already having a great impact on one of the most important industries in the world, but it is still poorly understood how the sector emerged. Two different but complementary evolutionary approaches can help with understanding how the fintech sector has gained a market presence over the last couple of years, and what the drivers behind the innovations were in the financial sector. The approach of Arner, Barberis and Buckley focuses on the source of the financial innovation of the past two centuries by distinguishing three distinctive phases of development. The phases follow each other but with shorter cycles, indicating the dynamic changes that have occurred with infrastructure and sources of innovation. The authors do not restrict the term fintech to current trends, but use it to describe an ever-evolving and innovatory financial sector with changing dynamics and actors.

Arner et al. offers an overview of financial innovation from the perspective of actors, focusing less on the evolution of resources and design in the financial sector. This study supplements the actor-based evolutionary approach by providing a resource and capability-based evolutionary perspective. By focusing more on skills and knowledge 
rather than actors, different information and viewpoints emerge. By understanding the differences between incumbents and challengers, replicable operating and business models can be drawn up so as to 1) provide a better understanding of different market participants; and 2) foster sector-wide innovation by helping to shift the focus onto the key growth factors.

\section{An actor-based evolutionary approach to fintech}

Work by Arner, Barberis and Buckley classifies the evolution of fintech into three distinct phases. The first stage is Fintech 1.0, which lasted from 1866 - 1987. During this period the physical foundations of modern telecommunication infrastructure were laid down across the globe (including important milestones, such as the installation of transatlantic transmission cables). This stage was necessary in terms of the establishment of correspondent banking and increasing the global interconnectivity of financial institutions. This infrastructure is still in use by banks who seek to provide reliable services to their customers. Without this investment into infrastructure, the fertile ground for the current phase of current innovation would not exist.

The second stage, so-called Fintech 2.0, started in 1987 and lasted until 2008, the starting point of the financial crisis. During this stage, the traditional financial sector was developed. Banks became increasingly digitized and built significant IT infrastructure to support their operations, while ATMs and other innovative financial products and services were created. Central clearing houses, stock exchanges and international correspondent banking became widespread, and regulatory standards were drawn up. Fintech 2.0 was the birth of modern banking with its branch-focused business models that are used today by many banks. A great deal of innovation occurred during this phase, which was regarded as disruptive at the time. However, banks relied too much on their previous successes, and formerly adequate systems became obsolete.

The current stage, Fintech 3.0, is ongoing and involves both newly emerging technology-enabled financial service companies and traditional banking institutions. Arner et al. show that approximately 12 billion USD worth of investment had been channeled to startups by 2014. This sum of money is significant, but what is more astonishing is that during this time the older Fintech 2.0 institutions spent approximately 197 billion USD on investment into IT, much of which went to sustain their non-competitive legacy systems. The authors also call attention to the (low) level of IT literacy of traditional banks. Meanwhile, although new fintech startups may be the cradle of new financial technologies, there is no reason to excoriate traditional financial service institutions. The study comprises an insightful analysis of the evolution of fintech and highlights a pragmatic, actor-based approach. By focusing on the role and value-added of different stakeholders, one can see how the main driving force behind financial innovation has shifted throughout the years from large infrastructure providers to banks, and then to fintech.
The present study employs three different evolutional layers - ecosystem development, pioneering services, and human-centered design - to supplement Arner et al.'s phases of the evolution of fintech. Each evolutional layer has been of different added-value to the presently evolving financial sector, and together the concept of layers comprises a holistic resource and knowledge-based approach to the topic. Understanding the three layers in more depth explains how the financial sector has developed into its current state and may provide help to aspiring innovators. The key value drivers in each of the layers can be identified. The study borrows knowledge from recent business model innovations in other sectors (such as the hotel and travel industry), and also analyzes push and pull forces that have impacted financial innovation and the rapid advance of technology and the changing customer demands of generation $\mathrm{Y}$ and $\mathrm{Z}$.

\section{The resource-based approach of fintech}

The reason for differentiating between the two evolutionary approaches is that the fintech sector is less influenced by the origin of the technology - namely, who is undertaking the innovation - and more by value-added design, as described in detail in the article. The model with three layers is the author's own construction based on the most commonly mentioned value drivers in cited articles and books categorized into understandable and logical groups. The hierarchy of needs is not new, and dates back to Maslow (A Theory of Human Motivation, 1943). The author argues that adapting the model of hierarchical needs for embracing individual potential can be adapted to understand the success behind fintechs. The three layers described in the model each represent an evolutionary step that can be identified in the recent growth of financial technologies.

The first layer of innovation is the creation of an ecosystem fostered by technological progress and the cheap availability of basic telecommunication and IT services. This ecosystem layer includes developments in IT hardware and software technology, such as affordable computers, mobile phones, rapid internet penetration and basic areas of knowledge such as programming skills. Ecosystem enablers include advances in computer technologies such as cheap hardware, including desktop computers, laptops and also tablets, making it possible for fintech to obtain market share due to the low barriers to entry. Telecommunications infrastructure has been installed in all the major cities of the world, and experiments with internet-transmitting satellite drones are also at an advanced stage and may provide free internet to people living at the bottom of the pyramid. Mobile phones, including feature phones and smartphones, have become cheap commodities but increase the opportunities individuals have to interact in a deep, more connected way with others, and with modern payment infrastructure. Fintech has also been supported by the less visible but equally important development of infrastructure such as new banking systems that are not yet widespread but will replace current legacy core banking systems in the future. New banking and financial sys- 
tems with open application programming interfaces (API) and plug-and-play solutions are technical enablers specific to the financial and fintech sector.

Cheap hardware has made it possible for individuals with lower incomes to learn the new craft of computer programming, even by using free educational materials available on the internet. Countries such as India have built a modern economy by realizing the importance of creating reliable and cheap programming capacity and have specialized in offering outsourcing services to companies with a demand for IT workforce. Fintech is presently enjoying several advantages over the traditional banking sector. First, it is not reliant on core legacy systems (many of which are 30 years old and have been repeatedly patched with new additional services). The legacy systems of banks are heavy burdens on innovation as the core functionality and the underlying infrastructure is becoming obsolete. Changes to legacy systems and infrastructure are costly and impose operational risks on incumbents, often representing barriers to innovation. Fintech builds its business models around technology and software. It understands that IT is a major driver of success so invests heavily in state-of-the art programming capabilities, and builds core competencies around software development (Haas et al., 2015). In contrast, the IT departments of traditional banks are not prepared to respond quickly, and typically require almost a year of preparatory work (involving the development of IT road maps) before the beginning of each new business year. Modifications that have not been scheduled for the year typically have to be accepted through extraordinary approvals, in many cases requiring CEO approval. Due to this lack of agility and quick-to-market processes, banks are slower at responding, and their capacity for experimenting is weaker.

The second evolutionary layer concerns pioneering services built with the help of innovative business models and an open, innovation-focused approach. Business models "describe the rationale of how organizations create, deliver and capture value" (Osterwalder - Pigneur, 2010), and are instruments that link economic performance, innovation and organizational strategy (Boons - Wagner, 2009). Cheap mobile phones and computers, the internet and new business models have made it possible for fintech to grow exponentially, and reach millions of users cheaply. The ability of fintech companies to globally and cost-effectively scale up and distribute services is their core advantage and leaves incumbents lagging behind.

Fintech companies understand the power of tailor-made, simplified business models, and in many cases, focus on niche segments of the financial sector that provide unique forms of value to their customers. They also systematically cooperate with external partners. Open innovation is a widely-used approach to enhancing organizational capacity for innovation. Open innovation relies on the systemic use of outside-in, inside-out and coupled approaches. The process gives a company strategic flexibility, helps to reduce development cycles, and to streamline processes (Gassmann - Enkel, 2004).
There are approximately two billion adults in the world without access to banking services according to the latest 2014 Global Findex report ${ }^{1}$. This is a decrease of $20 \%$ compared to the 2.5 billion unbanked in 2011, and represents significant progress towards providing financial services to people living in poverty (World Bank, 2015). The most severely unbanked regions are Sub-Saharan Africa, the Middle-East, Latin America and Asia, which account for 2.2 billion financially unserved adults (McKinsey, 2010). The provision of personal financial services such as saving accounts, remittance transfers and loan instruments can help people at the bottom of the pyramid to rise out of poverty. Credit card companies, banks, fintechs, and mobile operators are playing a significant role in this and are generating additional revenue by tapping into this large customer segment. In doing so, they provide social services and have a major impact on the triple-bottom-line considerations of financial technology providers.

Social entrepreneurs have realized that technology is an enabler; a way to provide previously expensive services to people who live at the bottom of the pyramid. The under- or unbanked population now can access financial services such as micro loans, current accounts and remittance transfers. The success of Prof. Muhammad Yunus' Grameen Bank shows how previously underbanked citizens can improve their personal finances by taking out community-backed micro-loans for starting their own businesses. M-PESA, operated by Safaricom - a subsidiary company of Vodafone - has become the largest money transfer service in Kenya. M-PESA's success proves that mobile operators can play a major role in providing basic financial services to the 2.5 billion people at the bottom of the pyramid (Bhandari, 2016). Early adopters of the new services became living proof that "banking is not somewhere you go but something you do" (King, 2013). The question is whether the appearance of fintech at the bottom-of-the-pyramid can improve financial stability by working with lower margins and creating higher volumes of financial transactions, thus improving productivity (Haldane, 2016). Regardless, the democratization of the financial sector is already visible in terms of improved access to services.

Many early, pioneering services were offered in developing countries which leapfrogged to adapt new technologies, in doing so bypassing the use of traditional banks. Kenya, with a population of almost 55 million people, was significantly underbanked because banks found it unprofitable to open branch offices and manage current accounts for people with low disposable incomes. Almost 30\% of the population were living in extreme poverty, equivalent to less than one dollar per day, even in 2015 (FSD, 2016). Being able to work and make a living under such circumstances sometimes requires breadwinners to leave their homes to take up work in larger, more industrialized cities. However, remittance transfers in Kenya were costly and difficult to make, causing great inconvenience to both senders and receivers. Accordingly, M-PESA launched an innovative new service and business model in 2007 (Mas - Radcliffe, 2010) in the form of an electronic money ac- 
count linked to the mobile phone number of the user. This uses the technological infrastructure of the telecommunication company's mobile network and only requires users to have a cheap feature phone to make peer-to-peer payment transfers. The payment service became a huge success, with 14 million active accounts processing more than 425 million USD in payments - equivalent to $17 \%$ of total Kenyan GDP - in 2010 alone (Mas - Radcliffe, 2010). This is a clear example of the democratization of finance and shows how social value can be generated from adopting a triple-bottom-line perspective (Elkington, 1997).

India is another example of a country in which fintech companies are working with new business models to empower people living under extreme conditions. The population of the country is 1.311 billion, with a GDP of two trillion dollars a year (World Bank, 2016). Research by Bhandari shows that the population of India can be socio-economically classified into the shape of a pyramid. Approximately 420 million people, or $35 \%$ of the population, are vulnerable. The majority, close to 520 million people, may be classified as lower-middle class, while $19 \%$ of the population, or 228 million people, are middle class. The top two percent are either upper-middle class or rich. In India, close to $90 \%$ of payments are made in cash, indicating huge potential for growth in electronic transactions. Mobile penetration is close to $60 \%$ of the population, and there is rapid growth in the number of users with online data packages (Jutla - Sundararajan, 2016). The pyramid provides plenty of opportunities for fintech in the form of new e-commerce platforms, digital wallets and payment solutions. While serving the financial and economic well-being of Indians, with low overhead costs fintech entrepreneurs are more likely to profit than traditional banks. Indian startups raised a cumulative 3.5 billion USD in investment in the first half of 2015 alone, allowing users to leapfrog traditional services and start using technology-enabled financial services such as payment schemes.

Key value drivers in the pioneering services layer are the early successes with reaching some of the severely unbanked or underbanked populations, not only in sub-Saharan Africa but also in India. Building extensive branch networks in poor rural regions has not been considered profitable by banks, which generally decided to avoid such markets. Traditional bricks-and-mortar banks simply could not generate enough revenue on the micro-remittances individuals wished to make. Nor did lending to the underbanked appear to be a profitable business as such individuals traditionally could not meet the strict credit risk assessment criteria. While banks abandoned these regions, fintechs were keen to exploit the business opportunities inherent in serving two billion of the world's unbanked. By using technology and the preexisting infrastructural backbone built by telecommunications companies and banks, fintech could offer a previously unmined customer segment convenient and easy-to-obtain financial services at affordable prices. Low operating costs made it possible to generate sufficient profit by innovating new business models, cooperating with other industries, and listening to the actual needs of customers and end-users.
The third evolutionary layer consists of the development and conscious use of human-centered design, by providing a toolset and experimental framework on top of business models and open innovation. The development of new financial products and services by non-banks was fueled by a loss of faith in traditional banks due to the catalytic role they played in the financial crisis that started in 2008. The Great Recession raised concern about the lack of transparency and misconduct of the traditional banking sector, significantly damaging public trust. Fintech companies rapidly gained market share over banks, which, as with the whole financial sector, had been on the verge of collapse, mainly for the following reasons: i) public and corporate lending dried up during the financial crisis due to an increase in risk aversion in the traditional banking sector, ii) interest rates moved close to zero, and were sometimes negative - discouraging the accumulation of wealth in savings accounts, iii) the public image of banks was severely damaged, iv) technology companies gained momentum by disrupting traditional capital-and-property-intensive industries such as the hotel industry and transportation sector; $v$ ) the number of tech billionaires increased significantly - Facebook alone had 10 billionaires at the time of its IPO (Business Insider, 2012) - suggesting to investors that technology-enabled disruptors were a high-risk but high-reward investment.

Fintechs soon understood that public disappointment in banks was creating an opportunity for better services and more user-centric innovation. Such companies started to invest time, money and effort in innovating new and distinctive service designs, understanding 'customer journeys' and mapping out routes for a frictionless user experience. Whether consciously or not, design was a key element of this process. Design thinking refers to much more than the conventional use of graphics and objects one typically associates with designers such as painters or sculptors. IDEO, one among the most successful design companies, long ago moved from designing artifacts to designing complex client experiences and new services. This holistic approach to design thinking may incorporate how a company reaches customers, what value proposition it offers, what the underlying business model is and how the customer journey is built from the first encounter through to all the touch points by which customers interact with the service. The analysis of Zilahy supports the view that new business models were a driving force behind the growth of sustainable sharing economy models that could utilize idle resources (Zilahy, 2016). Design thinking is creating a competitive advantage for fintech by generating the rapid, user centered prototyping of new services that are viable, desirable and feasible at the same time. Incumbents are faced with the decision either to adapt to new trends or risk losing their existing market share in certain lucrative segments. One report by $\mathrm{PwC}$ indicates that $20 \%$ of incumbents' revenue stream will be at risk from fintech entrants by 2020. More strikingly, banking and payment-related revenue is also at risk (28\%, and $22 \%$ higher risk, respectively) in areas such as insurance, asset and wealth management (PwC, 2016). 
The user experience is a key area in which fintech is superior to traditional, bricks-and-mortar banks. Frictionless, well designed, rapid services are the key success factors in the rapid growth of cloud-enabled fintech companies. Fintechs design their services to be available from all types of digital devices, including mobiles, tablets and even smart watches in some cases. Customers no longer have to wait in bank branches to make simple credit transfers, or to open bank accounts. Millennials (i.e. those born in the 1980s and 1990s) are looking for different, more personalized and convenient services from their banks. Research by Viacom Media found that 53\% of Millennials do not think that their bank is in any way more special or offers something different to other banks. More interestingly, $71 \%$ would rather go to the dentist than listen to what banks are saying, and $33 \%$ of them would be willing to switch banks in the next ninety days. Meanwhile, disruption is welcome: the research also states that $73 \%$ of this young generation would be excited by a new financial service offering from trendy, non-financial service providers. Fintechs also gain market share by offering personalized, point-of-purchase solutions based on analytics, the extensive use of multi-source data mining, and pattern recognition. Personal financial management tools help customers to manage their money more wisely with services such as automatic warnings about potential overspending. Crowdsourced solutions that give customers more control of their financial decisions are gaining traction. The first peer-to-peer lending platform in the world, gained momentum by developing a risk model that more accurately predicts credit defaults than banking systems do (King, 2014). Since the launch of the platform in 2005, the company's algorithms have analyzed data about customer behavior and even social media presence to establish individual risk profiles for each of its users in order to provide them with competitive lending opportunities.

A summary of the value-drivers in each layer is presented in Table 3.

Table 3.

\section{Key value drivers behind fintechs}

\begin{tabular}{|c|c|}
\hline Layer & Key value drivers \\
\hline $\begin{array}{l}\text { 1st Layer } \\
\text { (Top layer) } \\
\text { - Human- } \\
\text { centered } \\
\text { design }\end{array}$ & $\begin{array}{l}\text { - State-of-the-art customer and data analytics } \\
\text { - Superior user experience } \\
\text { - Experimenting, design-thinking approach }\end{array}$ \\
\hline $\begin{array}{l}\text { 2nd Layer } \\
\text { (Middle } \\
\text { layer)- } \\
\text { Pioneering } \\
\text { services }\end{array}$ & $\begin{array}{l}\text { - Rapidly scalable services } \\
\text { - Open innovation approach } \\
\text { - Disruptive business models }\end{array}$ \\
\hline $\begin{array}{l}\text { 3rd Layer } \\
\text { (Bottom } \\
\text { layer) - } \\
\text { Ecosystem } \\
\text { developments }\end{array}$ & $\begin{array}{l}\text { - Cheap mobile phones and internet access } \\
\text { - Cheap IT hardware and software } \\
\text { - Global telecommunication infrastructure }\end{array}$ \\
\hline
\end{tabular}

The platform provides lenders and borrowers with the opportunity to interact and engage in business transactions with each other under tolerable conditions of risk. Loan defaults are less than $0.5 \%$, compared to the $7.6 \%$ incurred by the average British bank, while average margins on loans are $3 \%$, much below the average $8 \%$ of their bricks-and-mortar counterparts. The lending platform has grown at $60 \%$ year-on-year since its inception, and now owns $3 \%$ of the U.K. retail lending market, having lent 400 million GBP so far (King, 2014).

\section{The Hungarian payment landscape}

Providing an in-depth analysis of the Hungarian financial sector is not within the scope of this paper, and there are authors who have already significantly contributed to this task. However, as fintechs are starting to make it into mainstream Hungarian literature, with the first specialized fintech event, the Fintech \& Sales Demo Day organized in 2014, the author seeks to foster the discussion about financial technologies in the country's financial sector.

The Hungarian financial sector has a dual character in terms of the development of its position on the innovation adoption curve. On the one hand, elementary financial services and payment schemes are more saturated than in the U.S. financial market (for example). One good example of this is the role of checks in payments. Due to the historical development of its financial sector, checks still account for $22 \%$ of all U.S. payments; an undisputable reminder of the past. Although payment by check is steadily decreasing and paper checks have largely been converted into electronic formats, this method of payment still plays an important role in the U.S. financial sector (FRBSF, 2012). The Hungarian financial sector leapfrogged the use of checks and instead promoted the adoption of more modern bank-card payments and contactless payment transactions. Statistics from the Central Bank of Hungary show that the number of domestic bank card transactions increased by $19.1 \%$ between 2014 and 2015, reaching 300 million transactions a year, with overall growth of $18.6 \%$ in terms of the total processed volume of payment (MNB, 2015).

Countries with a developed infrastructural and financial sector are moving toward the so-called cashless economy, funneling the use of fiat currency into electronic channels. The number of electronic payments is a sign of a country's financial innovativeness. Public adoption of financial technologies is often evaluated in terms of the currently most popular enabler, bank cards. Rapid growth in bank card transactions is a positive sign of the evolving Hungarian financial sector, however, there has also been a steady increase in the use of cash over the past five years (Kajdi Varga, 2015). Statistics from the Central Bank show that there were 4,244 billion Forints in circulation in March, 2016 , up by $13 \%$ with regard to the number of banknotes, and by $14 \%$ in terms of volume on the previous year. The proportion of cash/GDP reached $12.8 \%$, with a significant increase in larger denomination notes (MNB, 2016). The amount of cash in circulation is also important from a triple-bottom-line perspective, as the cost to society of using 
cash is significant. Research by Turján et al. shows that maintenance of the current portfolio of payment instruments (cash, debit and credit card payments, along with money transfers) costs society 388 billion Forints a year, accounting for $1.49 \%$ of GDP. Shifting to a different mix of payments (including an increase in electronic forms of payment) could lead to significant savings for Hungarian society of as much as 103 billion Forints per year. It is important to highlight that while cash is the most widely used payment instrument, accounting for $77.49 \%$ of all payment transactions, the cost of cash transactions is also lowest, at 73.66 Forints / transaction (Turján et al., 2011). Accordingly, replacement of the use of cash by electronic payment instruments might appear counterintuitive at first, but it should be remembered that cash is only cheaper due to economies of scale. Without this advantage, it would be more expensive than the cost of electronic credit transfers and direct debits. Hungary is not the only country to rely heavily on cash: the hoarding of cash is significant across Europe, with an estimated 400 billion Euros of savings kept in cash (Global Cash Report, 2015). The cost of cash in the U.S. is estimated to be 200 billion Dollars a year, amounting to 1,739 dollars for each household, or $3.3 \%$ of median household income (Chakravorti - Mazzotta, 2013).

Reforming the financial sector to bring it into line with its international counterparts is one of the aims of emerging Hungarian fintech. The fintech sector in Hungary is yet to evolve into a significant market segment, but it is already having an impact on traditional banks through the increasing number of companies, which have already started providing services on markets. Some sectoral growth has been fueled with money from EU Operational Programs, as research by the Fintech Group shows. Thirteen Hungarian fintech ventures were granted a total of four billion Forints of EU funding, while more than 35 self-funded (or venture-capital funded) fintech and insurtech projects have sprung up (Fintech Group, 2016).

Fintech companies in Hungary can move ahead by rolling out new, user-focused services due to the fact that the Hungarian banking sector has been facing severe challenges in recent years, and innovation has not been their highest priority. The financial crisis of 2009-2012 and increased regulatory attention (such as Basel II) froze the budgets of many banks. Many of them survived by imposing strict a freeze on hiring, and reducing the scope of traditional branch networks, by at least $50 \%$ in many cases. Following the international trend towards the digitization of banking services and the growing interest in technology-aware banking leadership, some major Hungarian banks have already decided to collaborate, not to compete, with emerging fintech startups. These digital transformation projects are likely to become more common for banks in the coming years and will be a test-bed for fintech companies who are prepared to cooperate. Such initiatives are likely to result in the rapid growth of innovative business models, user-centered fintech solutions, cheaper and faster electronic payment methods, and a wider range of services that help people to more effectively manage their day-today finances.

\section{Conclusion}

This article offers the conceptual understanding and groundwork to understand the rapid and successful growth of newly emerging financial technologies. By providing a clear definition of fintech, the author aims to improve the consistency of terminology used by researchers who analyse the fintech sector with regard to regulatory aspects and value-added design. Furthermore, the article specifies the importance of fintechs in the larger context on the global economic, social and environmental dynamics. The triple-bottom line impact of financial technologies is already affecting countries, which are increasingly enabled to leapfrog the burdens imposed by traditional brick-andmortar banks, and will play a role in the provision of financial services to millions of people living at the bottom of the pyramid.

The article fills a gap in current research by providing a resource-based analysis of the key value drivers behind the creation and growth of fintech companies. The exponential growth in the number of fintech companies can be explained with reference to at least three distinctive evolutionary forces. First, companies realized that technology (and especially software) were creating a great opportunity to innovate new services and products. The ecosystem built around IT technology, the internet and mobile phones enabled companies to grow quickly and sometimes exponentially, while marginal costs decreased with each additional software user.

Second, the success of technology companies proved that new business models and an open approach to cooperating with the ecosystem and other industries offered lucrative business opportunities.

Third, users were placed at the center of design in new business models and services, resulting in more user-friendly services. The systemic use of prototyping and design created services that offered a faster, cheaper and frictionless experience for users. These new designs enabled services to succeed, and many times expand virally to new users.

The ongoing changes in the financial landscape are already affecting the under- or completely unbanked, and are creating convenient and easy-to-use solutions in areas formerly without such services. Although the new global trends are receiving increasing attention from many kinds of stakeholders, in Europe (and especially in Hungary), the phenomena of fintech is a new and under-researched territory. Unfortunately, little primary data is available about the economic, social and environmental impact of fintechs. To the author's, knowledge, no broad, global fintech-specific scientific research has so far been carried out so far on the subject, nor the moral hazards and effect of potential defaults of currently well-funded startups are understood, but there is a clear awakening of interest in the field.

\section{Note}

1 The survey was initiated by the World Bank and carried out by Gallup, a global research institute. 


\section{References}

Accenture (2015): The Future of Fintech and Banking: Digitally disrupted or reimagined?

Agarwal, S. - Hauswald, R. (2010): Distance and private information in lending. The Review of Financial Studies, 23(7), p. 2757-2788.

Arner, D. W. - Barberis, J. N. - Buckley, R. P. (2015). The Evolution of Fintech: A New Post-Crisis Paradigm? Available at SSRN 2676553.

Bachmann, A. - Becker, A. - Buerckner, D. - Hilker, M. - Kock, F. - Lehmann, M. - Funk, B. (2011): Online peer-to-peer lending-a literature review. Journal of Internet Banking and Commerce, 16(2), p. 1.

Beck, T. - Demirgüç-Kunt, A. - Levine, R. (2000): A new database on the structure and development of the financial sector. The World Bank Economic Review, 14(3), p. 597-605.

Bhandari, M. (2016): India and the Pyramid of Opportunity. In: The FinTech Book: The Financial Technology Handbook for Investors, Entrepreneurs and Visionaries, p. 81-83.

Bhattacharya, S. - Thakor, A. V. (1993): Contemporary banking theory. Journal of Financial Intermediation, 3(1), p. 2-50.

Bikker, J. A. - Haaf, K. (2002): Measures of competition and concentration in the banking industry: a review of the literature. Economic \& Financial Modelling, 9(2), p. 53-98.

Boons, F. - Lüdeke-Freund, F. (2013): Business models for sustainable innovation: state-of-the-art and steps towards a research agenda. Journal of Cleaner Production, 45, p. 9-19.

Boons, F. - Wagner, M. (2009): Assessing the relationship between economic and ecological performance: Distinguishing system levels and the role of innovation. Ecological Economics, 68(7), p. 19081914.

Bruen, J. (2015): Fintech Unicorn List Q2 2015: An Estimated 46 Have Arrived +38 On Their Tails. http://finovate.com/fintech-unicorn-list-q2-201546-arrived-37-closing-in/

$C B$ Insights (2017): The CB Insights Fintech 250. https://www.cbinsights.com/research-fintech250

Chan, Y. S. - Thakor, A. V. (1987): Collateral and competitive equilibria with moral hazard and private information. The Journal of Finance, 42(2), p. 345363.

Chesbrough, H.W. (2007): Business model innovation: it's not just about technology anymore. Strategy \& Leadership, 35(6), p. 12-17.

Cordeiro, T. - Weevers, I. (2016): Design is No Longer an Option-User Experience (UX) in FinTech. In: The FinTech Book: The Financial Technology Handbook for Investors, Entrepreneurs and Visionaries, p. 34-37.

Dahlander, L. - Gann, D. M. (2010): How open is innovation? Research Policy, 39(6), p. 699-709.
Desai, F. (2015): The Fintech Boom and Bank Innovation. Forbes, https://www.forbes.com/sites/ falgunidesai/2015/12/14/the-fintech-revolution/\#1202f56249d0

DeYoung, R. - Glennon, D. - Nigro, P. J. (2006): Borrower-lender distance, credit scoring, and the performance of small business loans.

Doganova, L. - Eyquem-Renault, M. (2009): What do business models do?: Innovation devices in technology entrepreneurship. Research Policy, 38(10), p. $1559-1570$.

Douglas, J. L. (2016): New Wine Into Old Bottles: Fintech Meets the Bank Regulatory World. North Carolina Banking Institute, 20(1), p. 17.

Elkington, J. (1997): Cannibals with forks. The triple bottom line of 21 st century, 73. p.

Enkel, E. - Gassmann, O. - Chesbrough, H. (2009): Open R\&D and open innovation: exploring the phenomenon. R\&D Management, 39(4), p. 311-316.

Ernst\&Young (2016): German FinTech landscape: opportunity for Rhein-Main-Neckar

Federal Reserve Bank of San Fransisco (FRBSF) (2012): Is the Fed still in the business of processing checks? http://www.frbsf.org/education/publications/doctor-econ/2012/april/check-processing

Haas, P. - Blohm, I. - Peters, C. - Leimeister, J. M. (2015): Modularization of Crowdfunding Services: Designing Disruptive Innovations in the Banking Industry. Association for Information Systems

Haldane, A. (2016): Finance Version 2.0. Speech. Bank of England, 7.

Jutla, S. - Sundararajan, N. (2016): India's FinTech Ecosystem. In: The FinTech Book: The Financial Technology Handbook for Investors, Entrepreneurs and Visionaries, p. 56-57.

Kajdi L. - Varga L. (2015): Készpénzmentes társadalom - Álom vagy valóság. Central Bank of Hungary $(\mathrm{MNB})$

Kim, Y. - Park, Y. J. - Choi, J. (2016): The Adoption of Mobile Payment Services for "Fintech". International Journal of Applied Engineering Research, 11(2), p. 1058-1061.

King, B. (2014): Breaking Banks: The Innovators, Rogues, and Strategists Rebooting Banking. New York: John Wiley \& Sons

Mas, I. - Radcliffe, D. (2010): Mobile payments go viral: M-PESA in Kenya. Capco Institute's Journal of Financial Transformation, No. 32, p. 169-183.

Maslow, A. H. (1943): A theory of human motivation. Psychological Review, 50(4), p. 370-396.

McAuley, D. (2015): What is FinTech? Wharton FinTech, 22.10.2015

McKinsey \& Company (2015): Cutting Through the FinTech Noise: Markers of Success, Imperatives For Banks. McKinsey \& Company, $18 \mathrm{p}$.

Morris, M. - Schindehutte, M. - Allen, J. (2005): The entrepreneur's business model: toward a unified perspective. Journal of Business Research, 58(6), p. 726-735. 
Osterwalder, A. - Pigneur, Y. (2010): Business Model Generation: A Handbook For Visionaries, Game Changers, And Challengers. New York: John Wiley \& Sons

$P w C$ (2016): Global Fintech Report, Blurred lines: How fintech is shaping the financial world? London: $\mathrm{PwC}$

Shontell, A. (2012): Meet the 10 Billionairs of the Facebook IPO. Business Insider. http://www.businessinsider.com/meet-the-10-billionaires-of-thefacebook-ipo-2012-5?op=1

van der Kleij, E. (2016): Tech Giants Becoming NonBank Banks. In: The FinTech Book: The Financial
Technology Handbook for Investors, Entrepreneurs and Visionaries, p. 31-33.

Viacom Media Networks (2013): The Millennial Disruption Index. Viacom

Zilahy G. (2007): Szervezetek közötti együttműködés a fenntartható fejlődés szolgálatában (Cooperation among the organisations in service of the sustainable development). Vezetéstudomány/Budapest Management Review, 38(4), p. 2-13.

Zilahy G. (2016): Sustainable Business Models What Do Management Theories Say? Vezetéstudomány/Budapest Management Review, 47(10), p. $62-72$. 